\title{
Occurrence of Escherichia coli in Wildlife from Different Habitats of Sarawak, Malaysia
}

\author{
LESLEY MAURICE BILUNG ${ }^{* 1}$, KHO KAI LING ${ }^{1}$, KASING APUN $^{1}$, MOHD TAJUDDIN \\ ABDULLAH ${ }^{2,3}$, MUSTAFA ABDUL RAHMAN ${ }^{2}$, CHEN YIK MING $^{1}$, ADOM \\ BENJAMEN $^{1}$, YEE LING CHONG $^{2}$ \& HASHIMATUL FATMA HASHIM ${ }^{1}$ \\ ${ }^{1}$ Department of Molecular Biology, ${ }^{2}$ Department of Zoology, Universiti Malaysia Sarawak, 94300 Kota \\ Samarahan, Sarawak, Malaysia; ${ }^{3}$ Kenyir Ecosystem Research Centre, Universiti Malaysia Terengganu, \\ 21030 Kuala Terengganu
}

\begin{abstract}
This study was carried out to assess the occurrence of Escherichia coli (E. coli) in the bats, birds and rodents as representative of wildlife from different habitats in Sibu and Kapit, Sarawak, Malaysia. A total of 682 swab samples were collected from wildlife hosts and screened for the bacteria E. coli and E. coli O157:H7 using standard microbiological methods and molecular techniques. The overall occurrence rates of $E$. coli among these hosts were $14 \%, 17 \%$ and $54 \%$ for bats, birds and rodents, respectively. The occurrence of $E$. coli was the highest in rodents regardless of the habitats. Isolated E. coli were then screened for E. coli O157:H7 by using a multiplex PCR with four primer pairs targeting for Shiga toxin producing genes (slt-I and slt-II), and the genes involved in biosynthesis of $\mathrm{O} 157$ antigen $(r f b \mathrm{E})$ and $\mathrm{H} 7$ antigen $\left(\mathrm{fliC}_{\mathrm{H} 7}\right)$. slt-I, slt-II and $r f b \mathrm{E}$ genes were not detected in any of the $E$. coli isolates. However, the gene encoding for $\mathrm{H} 7$ antigen was detected in $23 E$. coli isolates. This indicated that $E$. coli $\mathrm{O} 157: \mathrm{H} 7$ strain was not detected in the wildlife studied. Absence of $E$. coli O157:H7 in the wildlife studied indicated these wild animals do not serve as an important reservoir of $E$. coli O157:H7. However, precautions have to be taken as other group of pathogenic E. coli may pose a zoonotic risk for humans and other animals.
\end{abstract}

Keywords: Escherichia coli, occurrence, Sarawak, wildlife

\section{INTRODUCTION}

Escherichia coli belong to the family Enterobacteriaceae and is part of the normal microflora of the gastrointestinal tract of mammals and birds. However, some strains are identified as pathogenic $E$. coli by their ability to possess specific virulence factors and specific toxin-encoding genes (Nataro \& Kaper, 1998). Virulence factors for E. coli O157:H7 include the production of one or more shiga-toxin (Mead \& Griffin, 1998). Enterohemorrhagic E. coli O157:H7 are zoonotic pathogens associated with severe human illness such as hemorrhagic colitis, hemolytic uremic syndrome and thrombocytopenic thrombotic purpura (Caprioli et al., 2005).

E. coli $\mathrm{O} 157: \mathrm{H} 7$ was first recognized as a pathogen in 1982 during an outbreak of

*Corresponding author:mblesley@frst.unimas.my hemorrhagic colitis caused by the consumption of undercooked meat in Oregon and Michigan (Riley et al., 1983). Ground beef, cattle and other bovine sources have been identified as the main natural reservoir for E. coli O157:H7. Birds and rodents have also been reported to harbour E. coli O157:H7. For example, Wallace et al. (1997) reported the isolation of E. coli $\mathrm{O} 157$ from wild birds in Morecambe Bay and Lancaster, UK which implicated that wild bird can serve as potential vectors for the dissemination of $E$. coli O157:H7. Other animals such as swine in the United State also harboured potentially pathogenic E. coli $\mathrm{O} 157$ (Feder et al., 2003).

Polymerase Chain Reaction (PCR) assay represents good alternative to traditional typing methods for the diagnosis of Shiga toxin producing E.coli due to their simplicity, 
rapidity and specificity (Olsvik \& Strockbine, 1993). Multiplex PCR allows simultaneous detection of two or more different virulence genes in a single reaction, inevitably leads to a greater number of positive samples compared to conventional methods (Gallian, 2003). Multiplex PCR have been successfully employed to detect E. coli O157:H7 (Apun et al., 2003; Hu et al., 1999; Radu et al., 2001).

The surveillance of the epidemiology of these pathogenic microorganisms in wildlife is particularly important due to the increasing activities of translocation of wild animals which increased the possibility of disseminating the pathogenic bacteria. In addition, not much is known about the distribution of $E$. coli in wildlife of different ecological niche in Sarawak. Although we have reported the occurrence of $E$. coli in the selected wildlife from disturbed habitats in Sibu, Sarawak (Apun et al., 2011), to the best of our knowledge, there is no report on undisturbed forest in Sarawak. The surveillance of pathogenic enterobacteria in different ecological niche is important as the development has been reported to affect the diversity and distribution of microorganisms in the animal hosts (Gordon \& Fitzgibbon, 1999). Therefore, this study was conducted to survey the occurrence of E. coli in birds, bats and rodents from the five different sampling areas located in Sarawak. Birds, bats and rodents were chosen to represent wildlife due to previous reports that these animals can act as reservoirs for E. coli $\mathrm{O} 157: \mathrm{H} 7$ (Foster et al., 2006; Nielsen et al., 2004; Wallace et al., 1997).

\section{METHODOLOGY}

\section{Sample collection}

Small mammals and bird specimens were collected from five sampling habitats located in Sibu and Nanga Merit, Kapit during June 2008 and June 2009, respectively. Specimens were collected from a forest park which is a recreational park and an oil palm plantation area, in Sibu; as well as a human settlement area and a forest area located in Nanga Merit, Kapit, Sarawak. Both of the forest and recreational parks in Sibu consisted of urban forests located $10 \mathrm{~km}$ from Sibu Town. The oil palm plantation in Sibu is a peat swamp area surrounded by oil palm and rubber tree plantations. Nanga Merit is about $70 \mathrm{~km}$ from Kapit. The human settlement area, Nanga Merit is located along the bank of Rajang River, whereas the forest area with minor human habitation and activities is located near the bank of Beletik River, upstream of Merit River. Avian and fruit bats were captured using standard mist nets whereas insect bats were captured using harp traps. Cage traps were used to capture rodents. Identification of mammals and birds was done according to Payne et al. (1985) and Francis (2005), respectively.

Anal swabs of small mammals and cloacal swabs from avian specimens were collected using wet sterilised cotton buds and immediately stored in $900 \mu \mathrm{l}$ phosphate buffered saline (PBS). All the samples were kept at $4{ }^{\circ} \mathrm{C}$ until processed, usually within the same day. All of the samples were cultured directly on MacConkey agar (Oxoid, England) and incubated aerobically at $37^{\circ} \mathrm{C}$ for 24 hours at the sampling site. Isolates tentatively identified as $E$. coli were further plated on EMB agar (Oxoid, England) after taken back to the laboratory. Plates were examined for the presence of colonies with metallic green sheen, and colonies that exhibited this characteristic were stored in nutrient agar (Oxoid, England).

\section{Bacteria Identification}

All isolates were tested using gram-staining and a series of standard biochemical tests. The biochemical tests included Kligler Iron Agar, IMVIC test and motility test. E. coli reference cultures ATCC 25922 was included as a positive control. The bacteria were identified and the results were compared to the Bergey's Manual of Systematic Bacteriology (Krieg et al., 1984). The bacteria were further confirmed by using commercial identification kits, API 20E system (BioMerieux, France).

\section{DNA Isolation}

Bacterial total DNA of E. coli isolates was extracted using boiling extraction method as described by Gallian (2003) with minor modification. For the extraction of bacterial genomic DNA, E. coli isolates was cultured in $5 \mathrm{ml}$ Luria-Bertani broth (BBL, United States) overnight at $37^{\circ} \mathrm{C}$ with agitation at $300 \mathrm{~g}$. Overnight broth suspensions $(1 \mathrm{ml})$ were then 
centrifuged at $19,000 \mathrm{~g}$ for 5 minutes to collect the pellets. Pellets were re-suspended in $100 \mu \mathrm{l}$ of distilled water and boiled for 20 minutes. The lysed cells were then cooled on ice for another 20 minutes and centrifuged at 19,000 $\mathrm{g}$ for 3 minutes. The supernatant containing DNA was used as template in the multiplex PCR assay.

\section{Multiplex PCR assay for the detection of $E$. coli 0157:H7}

Multiplex PCR assay for genes encoding Shiga toxin I and II, antigen $\mathrm{O} 157$ and antigen H7 were performed in a single tube reaction. Four set of primers synthesized commercially by FIRST BASE Laboratory Sdn. Bhd. were used in this study. SLT-I and SLT-II primer sets are targeted for the Shiga toxin producing genes (slt-I and slt-II) while $\mathrm{Rfb}$ and $\mathrm{FLIC}_{\mathrm{h} 7}$ primer sets are targeted for the genes involved in biosynthesis of $\mathrm{O} 157$ antigen and $\mathrm{H} 7$ antigen, respectively. E. coli $\mathrm{O} 157: \mathrm{H} 7$ reference strains EDL 933 was included as a positive control. The primers used for the amplification of the Shiga-toxin genes were described by Meng et $a l$. (1997) and the detection of $r f b \mathrm{E}$ gene and $\mathrm{fliC}_{\mathrm{H} 7}$ gene were as previously reported by Gannon et al. (1997).

The condition for the multiplex PCR assay performed was as described by $\mathrm{Hu}$ et al. (1999). Each PCR was performed in a total reaction volume of $25 \mu \mathrm{l}$ containing $1 \mathrm{X}$ PCR buffer, $2.5 \mathrm{mM}$ Magnesium Chloride $\left(\mathrm{MgCl}_{2}\right)$ (Promega Corp, USA), $0.2 \mathrm{mM}$ dNTP mix (Promega Corp, USA), $0.2 \mu \mathrm{M}$ of primers SltIF/SltI-R, SltII-F/SltII-R, Rfb-F/Rfb-R, FLIC $_{\mathrm{H}^{-}}-$ F/FLIC $_{\mathrm{H} 7}-\mathrm{R}, \quad 1$ Unit GoTaq ${ }^{@}$ Flexi DNA polymerase (Promega Corp, USA) and 10 $\mu 1$ of DNA template. PCR amplification was performed using iCycler $^{\mathrm{TM}}$ Thermal Cycler (Bio-Rad, USA) as follows: Initial denaturation at $94^{\circ} \mathrm{C}$ for 5 minutes; 35 cycles of denaturation at $94^{\circ} \mathrm{C}$ for 30 seconds; annealing at $59^{\circ} \mathrm{C}$ for 1 minute; and extension at $72^{\circ} \mathrm{C}$ for 1 minute; followed by final extension at $72^{\circ} \mathrm{C}$ for 7 minutes.

\section{Gel electrophoresis}

A $10 \mu \mathrm{L}$ aliquot of each amplification product was analyzed using electrophoresis on $2 \%$ agarose gels cast and run in $1 \mathrm{X}$ TAE buffer. A 100-bp marker (Vivantis, Malaysia) was included in the gel. Gel was stained with ethidium bromide $(0.5 \mu \mathrm{g} / \mathrm{ml})$ and visualized using transmitted ultraviolet illumination and photographed using gel documentation system (AlphaDigiDoc RT).

\section{DNA sequencing}

The E. coli isolates that produced $\mathrm{fliC}_{\mathrm{H} 7}$ amplicon were sent for sequencing to determine the strain identity of the $E$. coli isolates. The amplicon of positive control $E$. coli $\mathrm{O} 157: \mathrm{H} 7$ reference strain EDL 933 was also sequenced as a control. PCR mixture was prepared in $75 \mu \mathrm{l}$ reaction volume. After PCR amplification, the amplified 625 bp product was purified from $2.0 \%$ agarose gels using a Gel Extraction Kit (Fermentas), according to the manufacturer's instructions. The purified fragment was verified via agarose gel electrophoresis. The confirmed purified products were sent to a commercial DNA sequencing service company (First Base, Malaysia).

Analysis of nucleotide sequences for homology search was performed using BLASTN 2.2.23 (Basic Local Alignment Search Tool) GenBank database available from National Center for Biotechnology Information (NCBI).

\section{RESULTS}

In this study, swab samples were collected from a total of 105 birds, 84 bats and 44 rodents in Sibu and 208 birds, 224 bats and 17 rodents in Nanga Merit and tested for the occurrence of E. coli. A total of 106 and 259 isolates of $E$. coli were isolated from wildlife collected from Sibu and Kapit respectively. The occurrences of the $E$. coli in wildlife from Sibu and Nanga Merit, Kapit are illustrated in Table 1 and 2.

The overall occurrences of $E$. coli isolated from the three sampling sites in Sibu were recently reported by Apun et al. (2011). In Nanga Merit, the overall occurrences of $E$. coli isolated from both sampling sites were $15 \%$, $17 \%$ and $82 \%$ for bats, birds and rodents, respectively.

A total of 47 and 82 E. coli isolates from Sibu and Nanga Merit respectively were tested in PCR assay. Of 129 isolates tested, none of the isolates generated $s t x 1, s t x 2$, and $r f b \mathrm{E}$ gene 
with the expected band size of $210 \mathrm{bp}, 292 \mathrm{bp}$ and 484 bp respectively. Flic $_{\mathrm{H} 7}$ gene of expected size of $625 \mathrm{bp}$ was detected in $14 \mathrm{E}$. coli isolates from Sibu and nine $E$. coli isolates from Nanga Merit as shown in Figure 1 and Figure 2. These isolates were recovered from three bats hosts, three bird hosts, eight rodent hosts in Sibu and five bats hosts, and four rodent hosts in human settlement area in Nanga Merit. Hence, the absence of stx 1 , stx 2 , and $r f b \mathrm{E}$ genes indicated that none of the $E$. coli isolates were E. coli $\mathrm{O} 157: \mathrm{H} 7$.

Table 1. Occurrence of $E$. coli in wildlife from Sibu, Sarawak.

\begin{tabular}{|c|c|c|c|c|c|c|}
\hline \multirow{3}{*}{$\begin{array}{l}\text { Sampling site } \\
\text { (Sibu) }\end{array}$} & \multicolumn{6}{|c|}{ Animal Source } \\
\hline & \multicolumn{2}{|c|}{ Birds $(n=105)$} & \multicolumn{2}{|c|}{ Bats $(n=84)$} & \multicolumn{2}{|c|}{ Rodents $(n=44)$} \\
\hline & $\begin{array}{c}\text { No of } \\
\text { samples } \\
\text { tested }\end{array}$ & $\begin{array}{c}\text { No }(\%) \\
\text { positive for } \\
E . \text { coli }\end{array}$ & $\begin{array}{c}\text { No of } \\
\text { samples }\end{array}$ & $\begin{array}{l}\text { No }(\%) \\
\text { positive for } \\
\text { E. coli }\end{array}$ & $\begin{array}{c}\text { No of } \\
\text { samples }\end{array}$ & $\begin{array}{c}\text { No }(\%) \\
\text { positive for } E . \\
\text { coli }\end{array}$ \\
\hline Forest Park & 30 & $8(27)$ & 17 & 0 & 11 & $4(36)$ \\
\hline Recreational Park & 19 & $6(32)$ & 39 & $8(21)$ & 10 & $4(40)$ \\
\hline Oil palm Plantation & 56 & $5(9)$ & 28 & $1(4)$ & 23 & $11(48)$ \\
\hline
\end{tabular}

Table 2. Occurrence of $E$. coli in wildlife from Nanga Merit, Kapit, Sarawak.

\begin{tabular}{lcccccc}
\hline Sampling site & \multicolumn{5}{c}{ Animal Source } \\
\cline { 2 - 7 } (Nanga Merit) & \multicolumn{2}{c}{ Birds $(\mathrm{n}=208)$} & \multicolumn{2}{c}{ Bats $(\mathrm{n}=224)$} & \multicolumn{2}{c}{ Rodents $(\mathrm{n}=17)$} \\
\cline { 2 - 7 } & $\begin{array}{c}\text { No of } \\
\text { samples } \\
\text { tested }\end{array}$ & $\begin{array}{c}\text { No }(\%) \\
\text { positive for } \\
\text { E. coli }\end{array}$ & $\begin{array}{c}\text { No of } \\
\text { samples }\end{array}$ & $\begin{array}{c}\text { No (\%) } \\
\text { positive for } \\
\text { E. coli }\end{array}$ & $\begin{array}{c}\text { No of } \\
\text { samples }\end{array}$ & $\begin{array}{c}\text { No (\%) } \\
\text { positive for E. } \\
\text { coli }\end{array}$ \\
\hline Human Settlement & 102 & $28(28)$ & 93 & $28(30)$ & 17 & $14(82)$ \\
Recreational Park & 106 & $7(7)$ & 131 & $5(4)$ & 0 & 0 \\
\hline
\end{tabular}

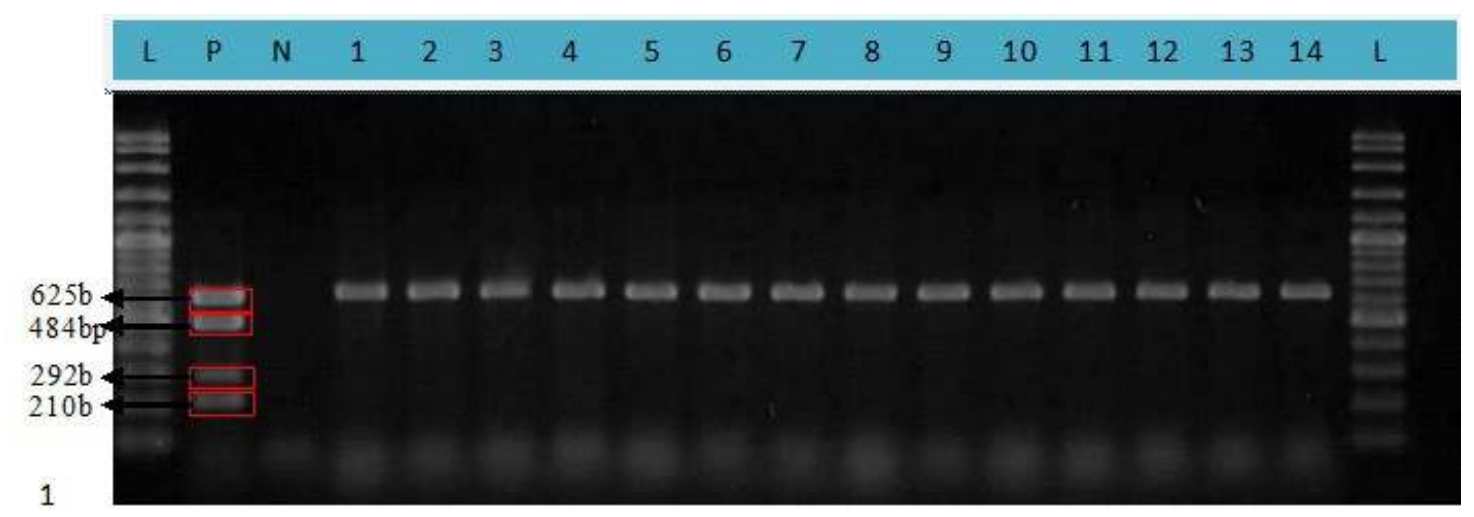

Figure 1. Amplicon obtained by multiplex PCR for the $14 \mathrm{E}$. coli isolates isolated from Sibu with fliC $\mathrm{H}_{7} \mathrm{gene}$ with expected size of 625 bp fragmented by $2 \%$ agarose gel electrophoresis. Lane L: 100 bp ladder, Lane P: E. coli $\mathrm{O} 157: \mathrm{H} 7$ reference strains EDL933 as positive control, Lane N: Negative control, Lane 1: Isolate (C0813) from bat sample in recreation park, Lane 2: Isolate (TK153581) from bat sample in recreation park. Lane 3: Isolate (TK153583) from bat sample in recreation park, Lane 4: Isolate (BA025) from bird sample in recreation park, Lane 5: Isolate (A2110) from bird sample in forest park, Lane 6: Isolate (TK156080) from rodent sample in oil palm plantation, Lane 7: Isolate (PL007) from rodent sample in oil palm plantation, Lane 8 : Isolate (PL010) from rodent sample in oil palm plantation, Lane 9: Isolate (PL011) from rodent sample in oil palm plantation, Lane 10: Isolate (PL0031) from rodent sample in oil palm plantation, Lane 11: Isolate (PL033) from rodent sample in oil palm plantation, Lane 12: Isolate (PL0035) from rodent sample in oil palm plantation, Lane 13: Isolate (PL0036) from rodent sample in oil palm plantation and Lane 14: Isolate (D0113) from bird sample in oil palm plantation. 


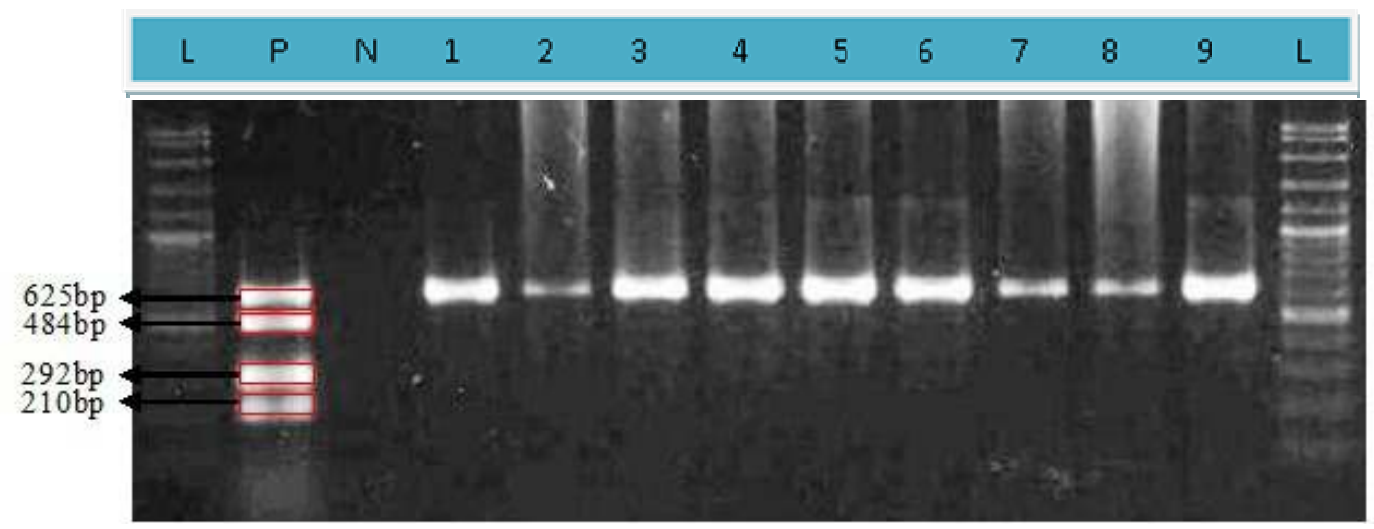

Figure 2. Representative amplicon obtained by multiplex PCR for the 9 E. coli isolates from Nanga Merit with $\mathrm{fliC}_{\mathrm{H} 7}$ gene with expected size of $625 \mathrm{bp}$ fragmented by $2 \%$ agarose gel electrophoresis. Lane L: $100 \mathrm{bp}$ ladder, Lane P: E. coli O157:H7 reference strains EDL933 as positive control, Lane N: Negative control, Lane 1: Isolate (U2021) from rodent sample in human settlement, Lane 2: Isolate (U2023) from bat sample in human settlement, Lane 3: Isolate (U2032) from bat sample in human settlement, Lane 4: Isolate (U2037) from bat sample in human settlement, Lane 5: Isolate (U2044) from rodent sample in human settlement, Lane 6: Isolate (U2049) from rodent sample in human settlement, Lane 7: Isolate (U2081) from bat sample in human settlement, Lane 8: Isolate (U2082) from bat sample in human settlement, and Lane 9: Isolate (U2117) from rodent sample in human settlement.

Seventeen representatives of $\mathrm{fliC}_{\mathrm{H} 7}$ ampliconpositive E. coli isolates were sent for sequencing for strain confirmation. Good sequences were obtained for all the $\mathrm{fliC}_{\mathrm{H} 7}$ gene sequence with high nucleotide sequence homology of $98 \%$ to $100 \%$. The amplicon of the positive control, E. coli $\mathrm{O} 157: \mathrm{H} 7$ strain EDL 933, matched with the $\mathrm{fliC}_{\mathrm{H} 7}$ gene for EDL in Genbank entries. The fliC $\mathrm{H}_{\mathrm{H}}$ amplicon for $E$. coli isolated from the wildlife in recreational park, Sibu aligned with $E$. coli reference strains $E$. coli $\mathrm{S} 88, E$. coli UT189, E. coli APEC 01, E. coli U5-41 flagellin genes from GenBank. Other fliC $\mathrm{H}_{7}$ amplicon for $E$. coli isolated from the wildlife in forest park, oil palm plantation and Nanga Merit human settlement area were aligned to $E$. coli reference strain 14097 flagellin gene from GeneBank.

\section{DISCUSSION}

In the five sampling habitats, rodents showed the highest occurrence of $E$. coli except for Nanga Merit forest area, where no rodent was captured. The occurrence of E. coli was always higher in rodents compared to birds and bats regardless of the habitats. The occurrence of $E$. coli in rodents $(43 \%)$ captured in Sibu was generally in accordance with the findings nrevinucly renorted hy Fordon and Courlino
(2001) where $42 \%$ of $E$. coli was detected in rodent hosts from Australia. Similarly, the occurrence of E. coli in birds captured in Sibu $(18 \%)$ and Kapit $(17 \%)$ was in general agreement with a study previously done by Gordon and Cowling (2001) in Australia where $23 \%$ of $E$. coli were found in the birds. The occurrences of $E$. coli in bats were $11 \%$ and $15 \%$ in Sibu and Nanga Merit, respectively. Adesiyun et al. (2009) reported a comparatively similar occurrence of $E$. coli $(13 \%)$ in bats in Trinidad and Tobago.

Among all of the sampling habitats, the occurrence of $E$. coli in rodents was the highest in Nanga Merit human settlement. In human settlement area, rodents had the closest association with human and the contaminated environment. From our observations during the fieldtrip, in human settlement site there was no designated area for waste disposal and the rubbish were scattered surrounding the long houses. Every household in the village lacked a proper sanitary system. As rodents live in close proximity to human, their food source may come from human wastes, garbage, food waste, or sewage effluent. In addition, rodents live on land where they frequently come into direct contact with soil and fecal matter which also served as reservoir for enteric pathogen (Santamaria \& Toranzos, 2003). 
Subsequently, these factors could potentially lead to a higher possibility of rodents to acquire $E$. coli from the contaminated surroundings. Thus, the occurrence of E. coli was always higher in rodents.

The occurrence of the E. coli in birds was the second highest in all of the sampling habitats except for human settlement area in Nanga Merit where occurrence of $E$. coli in birds and bats were comparatively similar. The presence of $E$. coli in birds can be attributed to its feeding habits where the bacteria could be picked from rubbish tips, sewage outfalls and consumption of contaminated food as reported by a previous study (Wallace et al., 1997). The occurrence of $E$. coli was high in the disturbed habitats with frequent human activities which consequently provide more opportunity for the birds to feed on contaminated food and water. According to Gordon and FitzGibbon (1999), animals such as birds living in close association with humans were more likely to have $E$. coli than animals living away from human habitation. Among all of the sampling sites, the occurrence of birds was the lowest in the forest area in Nanga Merit (7\%) which has the least perturbation where there were no human habitation and minimal human activity.

The occurrence of E. coli in bats captured from the human settlement area in Nanga Merit was the highest. Majority of the bats harboured $E$. coli were insect bats. The feeding method of insect bats which were insectivorous might be one of the transmission routes for $E$. coli. Transmission of $E$. coli might also occur after ingestion of contaminated food or water. Investigations concerning the interaction between bacteria and insect showed that insects served as reservoir for pathogenic E. coli (Ahmad et al., 2007; Khalil et al., 1994). Thus, insects or contaminated water were possible sources for $E$. coli. Great population densities of bats and their crowded roosting behaviour increased the chances of intra-species or interspecies transmission of the bacteria.

In the PCR screening of the anal and cloacal samples of wildlife in Sarawak, none of the $E$. coli isolates was positive for $E$. coli $\mathrm{O} 157: \mathrm{H} 7$ strains as none of the isolates displayed genes encoding for Shiga toxin 1, Shiga toxin 2 and gene involved in biosynthesis of O157 antigen.
In a recent research done by Kobayashi et al. (2009), E. coli $\mathrm{O} 157$ was not detected from the E. coli isolates from wild birds in Tokyo Bay, Japan. Similarly, in the study of wild birds in Scotland, only one out of 231 samples was positive for E. coli O157:H7 (Foster et al., 2006) which indicated a very low prevalence of STEC 0157 in wild birds. E. coli $\mathrm{O} 157: \mathrm{H} 7$ was also absent from wildlife in Trinidad and Tabago (Adesiyun, 1999).

In the PCR screening, $\mathrm{H} 7$ flagellar gene was detected in 23 E. coli isolates. Flagella and motility are critical elements in the virulence strategies of many bacterial pathogens. Erdem et al. (2007) demonstrated that the $\mathrm{H} 7$ flagella possess adhesive properties, particularly the ability to bind mucins, which contributed to colonization of mucosal surfaces. The $\mathrm{fliC}_{\mathrm{H} 7}$ amplicon for $E$. coli isolated from the wildlife in recreation park, Sibu aligned with those of $E$. coli reference strains $E$. coli IHE3034, E. coli S88, E. coli UT189, E. coli APEC 01, E. coli U5-41 flagellin genes from GenBank. These reference $E$. coli strains from GenBank were categorized as the extraintestinal pathogenic E. coli. Sequences analysis of the $\mathrm{fliC}_{\mathrm{H} 7}$ gene of the $E$. coli isolates from wildlife (three bat hosts and a bird host) in recreation park, Sibu were suspected to be associated with extraintestinal pathogenic $E$. coli as they shared 99\% homology in nucleotide sequences of the flagellin (fliC) gene from Genbank. The presence of $\mathrm{fliC}_{\mathrm{H} 7}$ gene in the suspected extraintestinal pathogenic $E$. coli isolated from these four wildlife hosts suggested a possible cross-interaction among the bats and birds allowing the transmission of the E. coli. Bats and birds might be sharing the same food sources contaminated with the $E$. coli strains. There was a possibility that bats and birds came into direct or indirect contact in the same habitat and played an important role in the dissemination of the $E$. coli strain. Other fliC $\mathrm{H}_{\mathrm{H}}$ amplicon for $E$. coli isolated from the wildlife in forest park, oil palm plantation and Nanga Merit human settlement site were aligned to $E$. coli reference strain 14097 flagellin gene from GenBank. E. coli reference strains belongs to serotype E. coli O153:H7:K- (Machado et al., 2000). E. coli O153:H7 was classified as enteropathogenic E. coli (Blanco et al., 2006) 
or enterohemorrhagic E. coli which had been reported to be isolated in rabbit (Garcia \& Fox, 2003). Thus, the detection of these strains indicated a possible risk of E. coli being transmitted from the wildlife to the environment and subsequently creating a zoonotic risk for human.

\section{CONCLUSION}

In conclusion, E. coli was isolated among the wildlife hosts in all of the habitats studied. Among the animal hosts, the occurrence of $E$. coli was shown to be always higher in rodents compared to other wildlife studied regardless of the habitats. The absence of E. coli O157:H7 indicated that bats, birds, or rodents from these habitats are not important reservoirs in the epidemiologic cycle of emerging enteric bacterial zoonoses in the state of Sarawak, Malaysia. However, the findings of other pathogenic E. coli strains raise concerns about the zoonotic risks for humans, given that the wildlife are in close proximity with humans.

\section{ACKNOWLEDGEMENT}

This project was funded by UNIMAS grants No: E14006/F07/06/ZRC/03/2007(03) and FRGS/01(19)/748/2010(34). The authors also would like to thank Mr. Wahap Marni, Mr. Besar Ketol, Mr. Azis Ajim, Mr. Dahlan Rambli, and all the staff and students from Zoology Department in the Faculty of Resource Science and Technology, Universiti Malaysia Sarawak who assisted in the sampling trip. Samples collected were approved by the State Planning Unit under permit (13) UPN/S/G1/I/10.1 Vol.26, 37/2008 for Forest Park Entrance Permit and NCCD.907.4 (IV) - 29 for sampling in Forest Park by Sarawak Forestry Department, TAPOP/GM/0508/11 by Ta Ann Plywood Sdn Bhd for sampling permit at oil palm plantation and also Majlis Perbandaran Sibu for approval letter to sample at recreational park.

\section{REFERENCES}

Adesiyun, A.A. (1999). Absence of Escherichia coli $\mathrm{O} 157$ in a survey of wildlife from Trinidad and Tobago. Journal of Wildlife Disease, 35:115-120.
Adesiyun, A.A., Johnson, A.S., \& Thompson, N.N. (2009). Isolation of enteric pathogens from bats in Trinidad. Journal of Wildlife Disease, 45:952-961.

Ahmad, A., Nagaraja, T.G., and Zurek, L. (2007). Transmission of Escherichia coli O157:H7 to cattle by house flies. Preventive Veterinary Medicine, 80:74-81.

Apun, K., Chang, P.P., Sim, E.U.H., \& Salleh, M.A. (2003). Survey of raw beef marketed in East Malaysia for Escherichia coli $\mathrm{O} 157$ and O157:H7. Journal of Bioscience, 14:49-56.

Apun, K., Kho, K.L., Chong, Y.L., Hashim, H. F., Abdullah, M.T., Rahman, M.A., Bilung, L.M., \& Lihan, S. (2011). Detection of Escherichia coli $\mathrm{O} 157: \mathrm{H} 7$ in wildlife from disturbed habitats in Sarawak. Research Journal of Microbiology, 6:132-139.

Blanco, M., Blanco, J.E., Dahbi, G., Alonso, M.P., Mora, A., Coira, M.A., Madrid., C., Juarez, A., Bernardez. M.I., Gonzalez, E. A., \& Blanco, J. (2006). Identification of two new intimin types in atypical enteropathogenic Escherichia coli. International Microbiology, 9:103-110.

Caprioli, A., Morabito, S., Brugere, H., \& Oswald, E. (2005). Enterohaemorrhagic Escherichia coli: emerging issues on virulence and modes of transmission. Veterinary Research, 36:289-311.

Erdem, A. L., Avelino, F., Xicohtencatl-Cortes, J., \& Giro' n, J.A. (2007). Host protein binding and adhesive properties of H6 and $\mathrm{H} 7$ flagella of attaching and effacing Escherichia coli. Journal of Bacteriology, 189:7426-7435.

Francis, C.M. (2005). A pocket guide to the birds of Borneo. Kota Kinabalu: Sabah Society.

Feder, I., Wallace, F.M., Gray, J.T., Fratamico, P., Paula, J., Fedorka-Cray, Pearce, R.A., Call, J.E., Perrine, R., \& Luchansky, J.B. (2003). Isolation of Escherichia coli O157 from intact colon fecal samples of swine. Emerging Infectious Disease, 9:380-383.

Foster, G., Evans, J., Knight, H.I., Smith, A.W., Gunn, G.J., Allison, L.J., Synge, B.A., \& Pennycott, T.W. (2006). Analysis of feces samples collected from a wild-Bird 
garden feeding station in Scotland for the presence of verocytotoxin-producing Escherichia coli O157. Applied and Environmental Microbiology, 72:22652267.

Gannon, V.P.J., D’Souza S., Graham, T., King, R. K., Rahn, K., \& Read, S. (1997). Use of the flagellar $\mathrm{H} 7$ gene as target in multiplex PCR assays and improved specificity in identification of enterohaemorrhagic Escherichia coli strains. Journal of Clinical Microbiology, 35:656-62.

Gallian, P. (2003). Detection and subtyping of shiga toxin producing Escherichia coli (STEC). In Sachse, K. and Frey, J. (Eds.). $P C R$ detection of microbial pathogens: Methods and protocols. Totowa: Human Press Inc. Pp.163-183.

Garcia, A. \& Fox. J.G. (2003). The rabbits as a new reservoir host of enterohemorrhagic $E$. coli. Emerging Infectious Disease, 9:15921597.

Gordon, D.M. \& FitzGibbon, F. (1999). The distribution of enteric bacteria from Australian mammals: host and geographical effects. Microbiology, 145:2663-2671.

Gordon, D.M., \& Cowling, A. (2001). The distribution and genetic structure of Escherichia coli in Australian vertebrates: host and geographic effects. Microbiology, 149:3575-3586.

Hu, Y., Zhang, Q., \& Meitzler, J.C. (1999). Rapid and sensitive detection of Escherichia coli O157:H7 in bovine faeces by a multiplex PCR. Journal of Applied Microbiology, 87:867-876.

Khalil, K., Lindblom, G-B., Mazhar, K., \& Kaijser, B. (1994). Flies and water as reservoirs for bacterial enteropathogens in urban and rural areas in and around Lahore, Pakistan. Epidemiology and Infection, 113:435-444.

Kobayashi, H., Kanazaki, M., Hata, E., \& Kubo, M. (2009). Prevalence and characteristics of eae- and stx- positive strains of Escherichia coli from wild birds in the immediate environment of Tokyo Bay. Applied and Environmental
Microbiology, 75:292-295.

Krieg, N.R., Holt, J.G., Murray, R.E.G., Brenner, D.J., Bryant, M.P., Moulder, J.W., Pfennig, N., Sneath, P.H.A., \& Staley, J.T. (1984). Bergey's Manual of Systematic Bacteriology Volume 1. United States: A Waverly Company.

Machado, J., Grimont, F., \& Grimont, P.A.D. (2000). Identification of Escherichia coli flagellar types by restriction of the amplified fliC gene. Research in Microbiology, 151:535-546.

Mead, P.S. \& Griffin, P.M. (1998). Escherichia coli O157:H7. The Lancet, 352:1207-1212.

Meng, J., Zhao, S., Doyle, M.P., Mitchell, S.E., \& Kresovich, S. (1997). A multiplex PCR for identifying Shiga-like toxin-producing Escherichia coli O157:H7. Letters in Applied Microbiology, 24:172-176.

Nataro, J.P. \& Kaper, J.B. (1998). Diarrheagenic Escherichia coli. Clinical Microbiology Reviews, 11:142-201.

Olsvik, O. \& Strockbine, N.A. (1993). PCR detection of heat-stable, heat labile and shiga-like toxin genes in E. coli. In Persing, D. H., Smith, T. F., Tenover, F. C., and White, T. J. (Eds.). Diagnostic Molecular Microbiology; Principles and application. United States: Mayo Foundation. Pp.271280.

Payne, J., Francis, C.M., \& Philips, K. (1985). $A$ field guide to the mammals of Borneo. Kota Kinabalu: The Sabah Society.

Peigne, C., Bidet, P., Mahjoub-Messai, F., Painvert, C., Barbe, V., Me'digue, C., Frapy, E., Nassif, X., Denamur, E., Bingen, E., \& Bonacorsi, S. (2009). The Plasmid of Escherichia coli Strain S88 (O45:K1:H7) That Causes Neonatal Meningitis Is Closely Related to Avian Pathogenic E. coli Plasmids and Is Associated with HighLevel Bacteremia in a Neonatal Rat Meningitis Model. Infection and Immunity, 77:2272-2284.

Radu, S., Ooi, W.L., Rusul, G., Karim, M.L.A., \& Nishibuchi, M. (2001). Detection of Escherichia coli O157:H7 by multiplex PCR and their characterization by plasmid profiling, antimicrobial resistance, RAPD 
and PFGE analyses. Journal of Microbiological Methods, 46:131-139.

Riley, L.W., Remis, R.S., Helgerson, S.D., McGee, H.B., Wells, J.G., Davis, B.R., Hebert, R.J., Olcott, E.S., Johnson, L.M., Hargrett, N.T., Blake, P.A., \& Cohen, M.L. (1983). Hemorrhagic colitis associated with a rare Escherichia coli serotype. New England Journal of Medicine, 308:681685 .
Santamaria, J. \& Toranzos, G.A. (2003). Enteric pathogens and soil: a short review. International Microbiology, 6:5-9.

Wallace, J.S., Cheasty, T., \& Jones, K. (1997). Isolation of Vero cytoxin-producing Escherichia coli 0157 from wild birds. Journal of Applied Microbiology, 82:399404. 